DOI 10.31558/2519-2949.2021.1.11

УДК $321.01 / 02$

ORCID ID: https://orcid.org/0000-0002-0392-4941

Мельник Ю. П., Одеська районна рада Одеськоӥ області

\title{
СТАНОВЛЕННЯ ІНСТИТУТУ ПОЛІТИЧНОЇ ВІДПОВІДАЛЬНОСТІ В КОНТЕКСТІ СУСПІЛЬНИХ ТА ОСОБИСТИХ ІНТЕРЕСІВ В ПЕРІОД НЕЗАЛЕЖНОСТІ УКРАЇНИ
}

\begin{abstract}
Проведення дослідження динаміки становлення політичної відповідальності в контексті особистих та суспільних інтересів, перш за все, поєднується з розумінням зміни акцентів в взаємній відповідальності органів публічної влади, політичних партій, інститутів громадянського суспільства, громадян та відгуку у вигляді рівня суспільної довіри, громадської активності, протестних суспільних настроїв та рівня задоволення життям в залежності від проведення вказаних змін та впровадження державних реформ. 3 метою з'ясування ступеню ефективності політичної відповідальності першочерговому дослідженню підлягають динаміка своєчасності ї̈ прояву та вивчення суспільної реакції за вищевказаними критеріями.

Встановлено, щу в залежності від зміщення державно-управлінських акиентів в бік парламентсько-президентської чи президентсько-парламентської форми правління в Україні, змінювалися й інструменти, процедура та розподіл політичної відповідальності та, як наслідок, підзвітність та підпорядкованість суб'єктів політичної системи. Вказані «зміщення акиентів», першочергово, були обтрунтовані вимогами політичної ситуацї̈ всередині краӥни, суспільними настроями, декларуванням різних векторів розвитку внутрішньої та зовнішньої політики та прийняттям за основу ставлення міжнародних організаиій до внутрішніх подій та рішень.

Вивчення особливостей становлення політичної відповідальності в період незалежності України, надало змогу встановити п'ять періодів зміни інструментального апарату політичної відповідальності, які напряму пов'язані із зміною форми державного правління.

В результаті проведеного дослідження були виокремленні два раніше не вказаних в науковій літературі види політичної відповідальності - зміна форми державного правління, як політична відповідальність попередньої влади, люстрацію як інструмент політичної відповідальності державних службовиів.
\end{abstract}

Ключові слова: політична відповідальність, суспільні та особисті інтереси, державне правління, політичний інститут, політична система,

Розвиток української соціально-політичної системи за демократичними принципами на засадах ліберальної, правової, соціальної держави, перетворює на одне із основних сучасних завдань дотримання гармонійного стану суспільних та особистих інтересів за допомогою державних та позадержавних механізмів та інструментів управління на основі природніх зв'язків особистості та суспільства за горизонтальним та вертикальним принципами. Одним із універсальних засобів впливу на гармонійний стан суспільних та особистих інтересів, який поєднує державну та позадержавну складові, $\epsilon$ політична відповідальність. В вказаному контексті вивчення розвитку інституту політичної відповідальності в контексті змін суспільних настроїв українського населення 3 метою вибору правильних шляхів її подальшого вдосконалення набуває особливої актуальності.

Мета та завдання. Вивчити основні етапи становлення політичної відповідальності в контексті змін рівня довіри, рівня задоволення життям, громадської активності та протестних настроїв населення в період незалежності України.

Методи дослідження. Методологічна основу дослідження складають інституційний та системний підходи, історичний та порівняльний методи. На основі інституційного та системного підходу було виокремлено коло суб'єктів та основні інститути політичної відповідальності, з'ясовані іiї основні інструменти. Історичний метод досліджень був застосований при виокремленні основних етапів розвитку політичної відповідальності. Порівняльний метод дослідження використовувався при проведенні аналізу співвідношення рівнів довіри інститутам влади та громадянського суспільства та протестних настроїв населення.

(C) Мельник Ю. П., 2021 
Виклад основного матеріалу. Початком першого періоду становлення політичної відповідальності в період незалежності України на рівні публічної влади та громадянського суспільства, можливо вважати запровадження інституту Президента з введенням в дію Закону УСРС від 5 липня 1991 р. «Про Президента Української РСР», що змінило вектори політичної відповідальності між органами публічної влади, створивши між ними конкуренцію, системну «залежність та підзвітність».

На законодавчому рівні був введений інститут імпічменту Президента за поданням Верховної Ради України з наступним розглядом Конституційним судом України. Президент отримав повноваження представляти визначений законом склад Кабінету Міністрів України та представляти i вносити пропозиції про звільнення Прем'єр-міністра України за погодженням з Верховною Радою України, мав право вето щодо законодавчих актів Верховної Ради України, мав право скасовувати акти Кабінету Міністрів, акти міністерств, органів виконавчої влади. У свою чергу Прем'єр-міністр мав право подання щодо призначення та звільнення інших членів Кабінету Міністрів. Таким чином, відповідно до архітектоніки розподілу підзвітності та контролю поміж органами публічної влади, була запроваджена парламентсько-президентська форма правління.

Інструментами політичної відповідальності органів публічної влади стали імпічмент, законодавче вето, скасування актів Кабміну, міністерств та органів виконавчої влади, примусове звільнення складу Кабінету міністрів України. Розпуск Верховної Ради України та законодавча ініціатива Президента України взагалі не передбачались.

Проведення перших парламентських та місцевих виборів в Україні відбулося на основі тимчасових Положень та згодом прийнятою Постановою Президії Верховної Ради України «Про порядок реєстрації громадських організацій» від 14 листопада 1990 р. Вказані дії були викликані гострою необхідністю зниження суспільної політичної напруги. Прийняття зазначених нормативних актів та запровадження багатопартійності на легітимній основі були інструментами підвищення суспільної довіри владі та гармонізації інтересів.

Прийняття доповнень до Конституції УРСР в 1992 р. остаточно легалізувало політичні об'єднання, проголосив право громадян України на них в ст. 32. Деталізував вказані положення Закон України «Про об’єднання громадян» від 16 червня 1992 р. Крім офіційного визначення, політичні партії отримали всеукраїнський статус. Порядок створення передбачав реєстрацію в Міністерстві юстиції України з подачею уставу, програми та підтримкою початку діяльності 1000 громадян України, які мають виборче право та обов'язок публікувати свої бюджети для загального відома, відповідальність за порушення фінансової дисципліни, також передбачалися штраф, тимчасова заборона окремих видів діяльності та розпуск у разі зменшення кількості членів політичної партії до числа, яке менше за визначене законодавством.

Інструментами політичної відповідальності політичних партій на першому етапі створення багатопартійної системи в Україні стали фінансове звітування, заборона проведення масових акцій, як можливих проявів національної та політичної нетерпимості, заборона видавничої діяльності з пропаганди фашизму та руйнування політичного устрою чи суверенітету, примусовий розпуск з причини втрати основної мети політичних партій - об’єднання громадян та представлення інтересів народу.

Слід зазначити, що на рівень гармонійності особистих та суспільних інтересів в українському суспільстві на початку 90-х років, за часів правління Президента Л. Кравчука, впливало багато факторів, від попередньої багаторічної ідеології та сформованого рівня суспільної та політичної культури, ціннісних вимірів, ідеалізації завжди правильного вибору реалізації політики державною владою до економічного занепаду, початку формування політичних еліт та груп інтересів, утвердження корупції як постійного явища в українському суспільстві.

3 причини існування ярко вираженого незадоволення рівнем життя з початку 90 -х років та не досягнення рівноваги інтересів та суспільного балансу завдяки політичним перебудовам, хибного розподілу політичної відповідальності поміж інститутом Президента та Верховною радою, розпочався конфлікт інтересів основних суб'єктів органів публічної влади, що на фоні економічної та суспільної кризи вилився в шахтарські страйки.

3 метою узгодження вказаної ситуації та стабілізації суспільної та урядової рівноваги, 8 червня 1995 р., поміж новообраним Президентом України Л. Кучмою та Верховною Радою України в особі О. Мороза був підписаний Конституційний договір про основні засади організації та функціонування державної влади і місцевого самоврядування в Україні на період до прийняття нової Конституції України, підписання якого стало початком другого періоду перерозподілу застосування інструментів політичної відповідальності в період незалежності України. 
Згідно положень вказаного Договору, була запроваджена президентсько-парламентська форма правління, що виявилася в значному посиленні інституту Президента - одноособове формування та очолення Кабінету Міністрів України, ускладнення процедури політичної відповідальності Верховної Ради України уразі застосування вето президентом України (зняття вето у разі повторного голосування простої більшості складу Верховної Ради було змінено на 2/3 від іï фактичного складу), право одноособового скасування актів Кабінету Міністрів України та центральних та місцевих органів державної виконавчої влади.

Попре вказаного, була збережена процедура політичної відповідальності Президента у вигляді імпічменту та введене вето указів Президента України Верховною Радою з одночасним поданням до Конституційного суду. Політична відповідальність кабінету Міністрів України набула подвійного статусу перед Президентом та перед Верховною Радою України, яка могла оголосити вотум недовіри всьому складу Кабінету Міністрів України.

3 прийняттям 28 червня 1996 р. Конституції України Президент втратив статус глави виконавчої влади та Кабінету Міністрів України. За Президентом зберігалось право ініціативи призначення та відставки Прем'єр-Міністра за погодженням з Верховною Радою України, яка передбачала відставку всього складу уряду, скасування актів Кабінету Міністрів України. Призначення та відставка складу уряду, керівників центральних органів виконавчої влади та голів місцевих державних рай адміністрацій відбувалося за поданням Прем'єр-міністра з наступним погодженням Президента України. Кабінет Міністрів одночасно був підзвітний Президенту України та Верховній Раді України, яка отримала право висловлення недовіри Кабінету Міністрів України більшістю від свого конституційного складу за рішенням Президента України.

Тенденціями зміщеннями акцентів політичної відповідальності на користь Президента стали: ускладнення зняття вето Президента шляхом збільшення кількості голосів при повторному голосуванні Верховної Ради України; скасування права Верховної Ради України ветувати укази Президента України; наділення Президента правом розпуску Верховної Ради України; одночасне ускладнення процедури імпічменту - зміни підстав імпічменту з «порушення Конституції та інших законів» на «вчинення державної зради або іншого злочину», встановлення кількості народних депутатів, які можуть розпочати процедуру імпічменту - більшість від конституційного складу Верховної Ради України, прийняття рішення про звинувачення Президента з голосуванням за нього народних депутатів в кількості не менше 2/3 від конституційного складу Верховної Ради України, запровадження додатково спеціальної слідчої комісії окрім висновку Конституційного суду України.

Динаміка рівня довіри до Президента України за роки незалежності України, свідчить про ріст довіри на початку строку його каденцій, та спаду рівня довіри як оцінки результату його діяльності після першого року правління, що, скоріше, свідчить про суспільну відмову від завищених очікувань покращення політичного та економічного стану країни, ніж про падіння реального рівня довіри до провладних інститутів.

Необхідно зауважити, що взагалі рівень суспільної довіри в Україні до інститутів влади в порівнянні з іншими країнами світу знаходиться на низькому рівні. В літературі цей факт пояснюється трансформаційним суспільним станом, впливом ідеології СРСР та нестійким політичним та економічним положенням, негативним впливом ЗМІ. Попри вказане, існують певні взаємозалежності поміж рівнем довіри до всіх публічних інститутів.

Спостерігається також загальна залежність позитивного коливання рівня довіри всіх державних інститутів в залежності від проведення виборів Президента України (Мал.1).

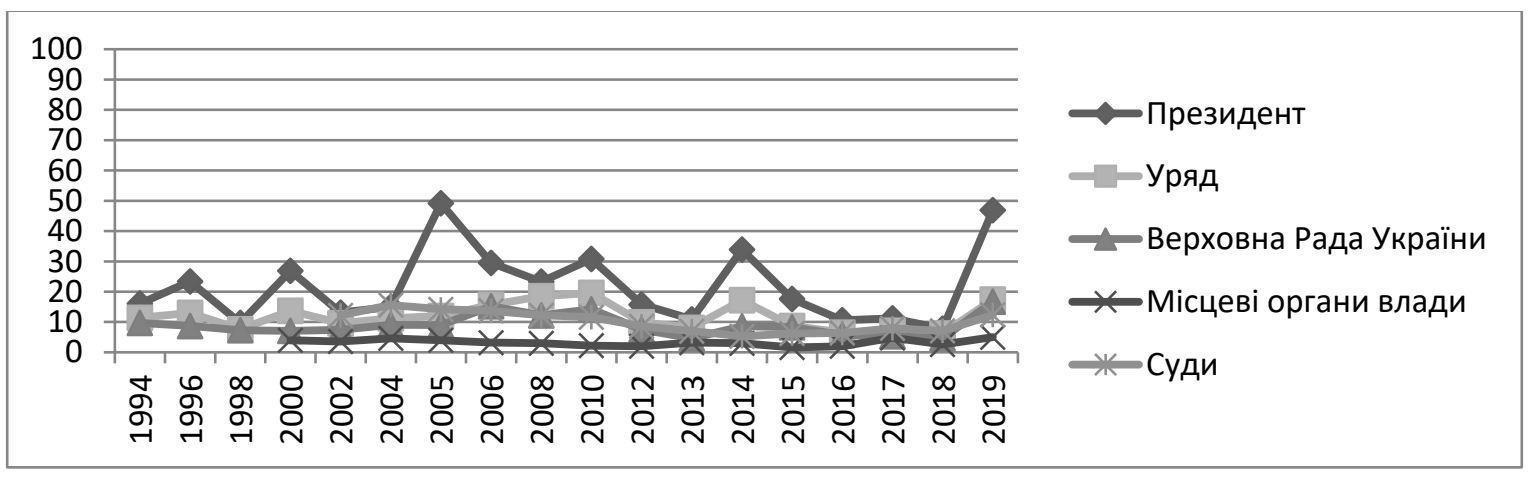

Мал. 1. Рівень суспільної довіри органам публічної влади за сумарним показником (Статистичні данні Інституту соціології НАН Украӥни) [1]. 
Перш за все, це пояснюється тим, що створення України на тлі спадку СРСР, очолення посади Голови держави професійними політиками до 2019 р., персоніфікувало завищену політичну відповідальність Президента країни, що втілювалося не тільки в психологічній свідомості українців, а й в періодичних спробах консолідації владних президентських повноважень.

Як результат, неконституційними інструментами політичної відповідальності Президентів України за час іiї незалежності стали шахтерський страйк 1993 р., Помаранчева революція 2004 р., Євромайдан 2013 р., Революція гідності 2014 р. та непереобрання на другий термін шляхом програшу виборів.

Необхідно підкреслити, що рівень суспільної довіри Верховній Раді України залишається досить низьким до моменту запровадження у другий раз парламентсько-президентської форми правління в 2004 р. О. Вишняк зазначає, що попри виборів до Верховної Ради України в 1994, 1998, 2002 рр. сплеск довіри до цього суб'єкту публічної влади не відбувся. Вказане пояснюється тим, що Верховна Рада України мала обмежені повноваження щодо формування Кабінету Міністрів України. Після їх набуття з введенням парламентсько-президентської форми правління, спостерігалося незначне підвищення рівню довіри до Верховної Ради [2, с.37].

Впливовими факторами заниженого рівня довіри до складу Верховної Ради України можуть також вважатися формування ії складу переважно із представників олігархату, історичне формування незмінного сегменту народних депутатів всіх іiі скликань, відсутність розпуску, який був майже незмінний після проведення позачергових виборів 1994 р. аж до 2007 p.

Дослідження рівня суспільної довіри до Кабінету Міністрів України теж наштовхує на висновки щодо взаємозалежності рівня довіри від проведення Президентських виборів, не дивлячись на постійне застосування інструментів політичної відповідальності за період незалежності: неоднократні зміни складу уряду, висловлення недовіри, розпуск, зміна його підзвітності, підконтрольності, процедури формування тощо.

Ще одним відомим актором в балансі особистих та суспільних інтересів, який має вагомий вплив на формування органів публічної влади $\epsilon$, як зазначалося у другому розділі дисертаційного дослідження, Конституційний суд України. Суспільна довіра до Конституційного суду трималася на рівні вищому за довіру до інших суб'єктів публічної влади, але його становище значно погіршилося з його остаточною політизацією в середині 2000 років [2, с. 38].

Введення більш складної системи підзвітності та підконтрольності органів публічної влади Конституцією 1996 р. повинно було відобразитися зростанням рівня суспільної довіри та підтримки діяльності діючої влади, гармонізацією відносин поміж інститутами влади та суспільством, але завдяки зовнішнім та внутрішнім факторам на фоні Конституційних змін відбулися інші процеси, що й підтверджується вищенаведеними статистичними даними.

Правління Президента в вказаний період, грунтувалось не тільки на політичному та законодавчому балансі інтересів, а й на особистих домовленостях з декількома групами інтересів, що й створювали значну противагу на вагах балансу особистих та суспільних інтересів. Порушений політичний баланс інтересів провладної еліти, суспільства й особистості створив передумови застосування самої жорсткої форми прояву дисблансу владних і суспільних відносин - революційних дій та, як наслідок, зміни форми правління, яке теж в контексті дослідження динаміки змін в українському державотворенні можливо віднести до інструментів політичної відповідальності.

Збільшення рівня відмітки показників суспільних опитувань щодо довіри органам публічної влади «зовсім не довіряю» до середньовзвішаного відсотку 35, говорило про початок кризи довіри в 2000 році.

Інструментом балансування суспільних та особистих інтересів було обрано проведення референдуму. Всеукраїнська народна точка зору, яка повинна була відобразитися на Конституційному рівні, та могла би вважатися понесенням фактичної політичної відповідальності Верховною Радою України, при тотальному звинуваченні державних службовців в корупції та бездіяльності, неодмінно стала фактором гармонізації суспільних та особистих інтересів в 2000 р. та піднесення рівня довіри до інститутів державної влади.

Але Верховна Рада України проголосувала проти впровадження результатів референдуму, за якими скорочувався ії склад та зміцнювався інститут Президента України, а згодом, 8 грудня 2004 р., у зв'язку із прийняттям змін до Конституції України, була запроваджена парламентськопрезидентська форма правління. Вказані події можливо вважати початком третього етапу застосування інструментів політичної відповідальності на державному рівні.

У зв'язку із зазначеними змінами відбувся перерозподіл функціонального навантаження щодо призначення складу Кабінету Міністрів України та Прем'єр-міністра України на користь Верховної 
Ради України, переглянута процедура його відставки та розпуск складу уряду - за пропозицією Президента та голосування за розпуск не менш ніж $1 / 3$ від складу парламенту чи прийняття рішення $2 / 3$ від складу парламенту. За Президентом зберігалось право розпуску парламенту після проведення консультацій з Головою Верховної Ради України, була введена партійна відповідальність народного депутату, індемнітет та фактично необмежена депутатська недоторканість. Право Президента щодо скасування актів уряду було збереження у вигляді права на призупинення актів уряду із паралельним зверненням до Конституційного суду.

Не дивлячись на суттєві перебудови та децентралізацію занадто консолідованої Президентської влади на Конституційному рівні, з 22 листопада 2004 р. по 23 січня 2005 р. на території України відбулось застосування самої жорсткої форми непокори - революційні дії, які мали класичні риси «кольорової» революції.

Продовженням становлення інституту політичної відповідальності, стало обрання 23 січня 2005 р. В. Ющенка на посаду Президента країни. В умовах запровадження парламентськопрезидентської форми правління, яка повинна була спрямувати деконцентрацію влади, політична ситуація в країні зазнала коливань, що призвели до нових більш жорстких змін.

Необхідно зазначити, що за період правління В. Ющенка конституційна форма політичної відповідальності застосовувалась неодноразово до Кабінету Міністрів України, а в 2006 р. були проведені позачергові вибори до Верховної Ради України з причини ії розпуску із-за неможливості своєчасного формування коаліції.

Ю. Мацієвський вказує, що, з метою удержання влади в своїх руках, в умовах протистояння 3 Пример-міністром, В. Ющенко посилив повноваження Секретаря Ради Національної безпеки та пішов на тактичний союз з «регіоналами» - 22 вересня 2005 р. був підписаний «Меморандум порозуміння поміж владою та опозицією». Формування коаліційної опозиції закінчилося підписанням Універсалу 3 серпня 2006р. поміж Президентом, Прем’єром, Головою Верховної Ради України та всіх депутатських фракцій, який в результаті перетворив В.Януковича на ключового гравця [3, с. 289-290].

Попри підписання політичних угод поміж конфронтуючими політичними сторонами, майже весь термін президентства $\quad$ В. Ющенка відбувалося парламентсько-президентське та урядовопрезидентське протистояння. За вказаний період Президент звертався до Конституційного суду України понад 100 разів [4, с. 52]. Лобіювання Президентських інтересів закінчилося політичним програшем на виборах 2010 р., що й стало основним інструментом політичної відповідальності Президента.

Не дивлячись на попередній регіональний конфлікт інтересів в українському суспільстві, 25 січня 2010 р. відбулася інавгурація В. Януковича, президентство якого закінчилося Революцією Гідності.

Необхідно відмітити, що середній бал рівня суспільної довіри до органів публічної влади помітно зріс одразу після обрання нового Президенту, але почав знижатися до пікової відмітки к кінцю 2013 р.

Поясненням вказаної тенденції може стати довід щодо посилення політики консолідації влади в руках Президента як і за часів Л. Кучми. Крім того, за Рішенням Конституційного Суду України від 30 вересня 2010 р., де-факто була повернена в дію Конституція 1996 р., відбулася зміна форми державного правління на президентсько-парламентську, перевагою якою було те, що вона не потребувала створення коаліції. 3 вказаними подіями можливо зв'язати початок четвертого етапу розвитку політичної відповідальності. Політичний баланс в системі органів публічної влади почав грунтуватися за жорстким вертикальним принципом, основаним на делегуванні повноважень за принципом дружби та спорідненості, який в ЗМІ та наукових дослідженнях отримав назву «кумовства» та «клієнтилізму».

Крім того, формування автократичних принципів побудови влади посилилось з виграшем місцевих виборів пропрезидентською партією та проведенням судової реформа, яка, фактично, заклала систему тотального контролю українських судів. Результати місцевих виборів та перерозподіл повноважень Кабінету Міністрів України щодо перерозподілу бюджету в 2011 р., надали можливість здійснення Президентом практично повного контролю виконавчої гілки влади.

Вказане, на фоні суспільного конфлікту поглядів на спрямування зовнішньої та внутрішньої політики, релігійних переваг, росту корупції, обмеження свободи слова, стали умовами настання всеукраїнської політичної кризи та, як слідство, застосування політичної відповідальності у вигляді революційних дій на фоні суспільного незадоволення життям (Мал. 2). 


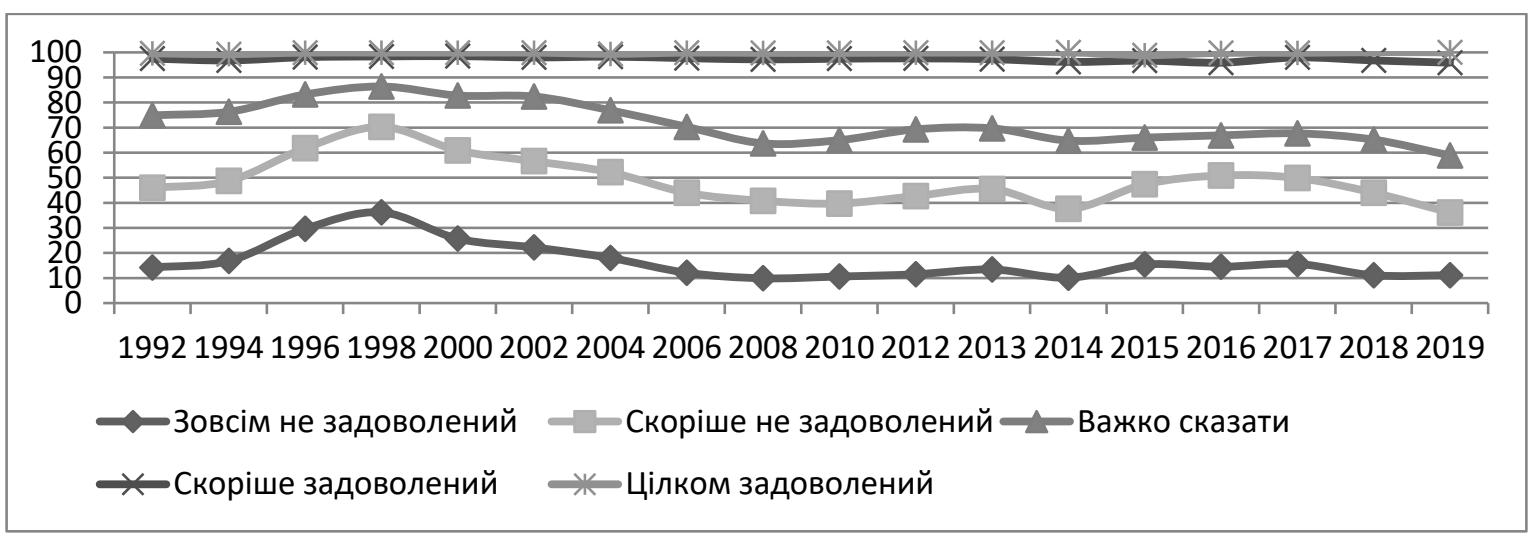

Мал. 2. Суспільне задоволення життям загалом (Статистичні данні Інституту соціології НАН Украӥни) [1].

Серед причин Свромайдану сучасні науковці вказують орієнтацію Півдня та Сходу країни на економічні зв'язки з Росією [5], що спричинило нерівномірний регіональний розвиток, обмеження демократичних прав та свобод [6], фальсифікація виборчого процесу, зростання соціальної напруги (політичну ситуацію вважають напруженою від 50\% опитаних в 1998 р., 64\% в 2010р, критичною 55\% в 2014 та 13,5 \% в 2019) тощо.

Вказане відобразилося й в загальному рісті протестних настроїв населення (Мал. 3).

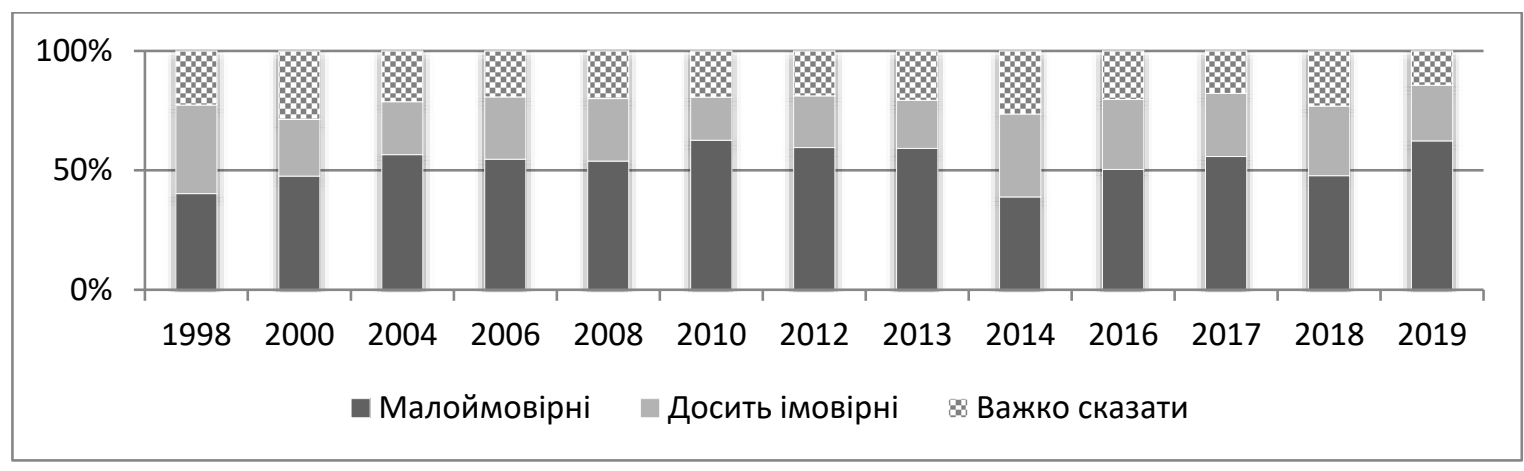

\section{Мал. 3. Суспільна думка щцодо масових виступів у власному місті (селі) проти падіння рівня жстття, на захист своӥх прав (\%) (Статистичні данні Інституту соціології НАН Украӥни) [1].}

Одним з основних інструментів політичної відповідальності 2014 р. стало не переобрання В. Януковича на другий термін в результаті його «побігу» з території України, констатація його «самовідсторонення» Верховною Радою України та шляхом простого голосування повернення до положень Конституції 2004 р., тобто до парламентсько-президентської форми правління, формування коаліції, призначення нового складу уряду та О. Турчинова виконуючим обов'язки Президента країни.

Необхідно відмітити, що в вказаній складній політичній ситуації відбулось перевищення повноважень Верховної Ради України та застосування ще одного виду конституційної політичної відповідальності - призначення позачергових виборів Президента.

25 травня 2014 р. Президентом було обрано П. Порошенко, який одразу розпочав підготовку реформи децентралізації влади та вніс на розгляд законопроект «Про внесення змін до Конституції (в частині децентралізації влади)». 1 квітня 2015 р. кабінет Міністрів України своїм розпорядженням схвалив концепцію «Про схвалення Концепції реформування місцевого самоврядування та територіальної організації влади в Україні» [7].

Ще одним вагомим досягненням Президента стала боротьба з корупцією та створення Національного антикорупційного бюро, Спеціалізованої антикорупційної прокуратури, Національного агентства з питань запобігання корупції, Антикорупційного суду. Необхідно 
підкреслити, що за вимірами Transparency International Індекс сприйняття корупції в Україні за часів В. Януковича почав струмко підійматися.

Також була запроваджена люстрація згідно із Законом України «Про очищення влади», що вступив в силу в жовтні 2014 p. [8], яку теж можливо вважати інструментом політичної відповідальності посадовців щодо обмеження доступу на зайняття державних посад, що у зв'язку із суспільним розумінням справедливості повинно було позитивно відобразитися на гармонійному стані інтересів суспільства та особистості.

Отримання Томасу про автокефалію Українською Православною церквою 6 січня 2019 р., додатково повинно було відіграти позитивну роль в піднесенні довіри до Президента П. Порошенка шляхом вирішення питань майнового характеру, збільшення кількості церков, монастирів та приходів Української православної церкви. Але в вказаний рік можливо було тільки спостерігати зниження рівня довіри до інституту Президента та релігійних організацій.

Не дивлячись на вказані дії, П. Порошенко хоча й, очевидно, намагався розпочати реформи, але зниження економічного добробуту населення, військові дії, звинувачення в популізмі запровадження антикорупційних заходів призвели до програшу ним виборів 2019 р. та переорієнтацією виборців на нову кандидатуру на політичній арені.

Висновки. Таким чином, дослідження динаміки застосування інструментів політичної відповідальності та іiі впливу на гармонізацію суспільних та особистих інтересів, свідчить про необхідність узгодження системи інструментів конституційної політичної відповідальності, яка першочергово залежить від розподілу владних повноважень поміж інститутами державної влади та від форми державного правління. Проведене дослідження надало змогу встановити п'ять періодів зміни інструментального апарату політичної відповідальності за період незалежності України, які тісно пов'язані із зміною форми правління.

Вивчення практичного застосування політичної відповідальності в контексті політичних змін на території України, дозволило виокремити два нових види політичної відповідальності - зміна форми державного правління, як політична відповідальність попередньої влади, люстрацію як інструмент політичної відповідальності державних службовців. Також було встановлено, що частіше всього піддається політичній відповідальності Кабінет Міністрів України.

Аналіз суспільної думки в динаміці, проведений на основі дослідження рівня суспільної довіри, громадської активності, протестних суспільних настроїв та рівня задоволення життям українського суспільства за роки незалежності, показав, що рівень довіри українського суспільства до інститутів державної влади та громадянського суспільства тісно пов'язаний із застосуванням неконституційного позадержавного інструменту політичної відповідальності - суспільним осудом. Дослідження зміни рівня довіри та суспільної активності в контексті застосування конституційних інструментів політичної відповідальності, показало відсутність їх взаємної пов'язаності, та персоніфікацію влади. Таким чином, суттєві зміни рівня довіри українських громадян за період незалежності України залежали від обрання Президента країни та росту протестних настроїв, які двічі закінчилися революційними діями. Вказані висновки ускладнює велика кількість опитуваних, які не можуть визначитися зі своєю точкою зору. Необхідно зазначити, що такий сегмент суспільної невизначеності в своєму відношенні до дій суспільно-політичних інститутів, свідчить про перехідний стан суспільства та не сформованість політичних інститутів взагалі.

\section{Бібліографічний список:}

1. Українське суспільство. Моніторинг соціальних змін. Збірник наукових праць. Заснований Інститутом соціології НАН України. Київ, 2019. Вип. 6 (20). 517 с.

2. Вишняк О. Довіра до політичних інститутів: поняття, показники та тенденції змін. Українське суспільство 1992-2010. Соціологічний моніторинг / за ред. В. Ворони, М. Шульги. Київ: Ін-т соціології НАНУ, 2010. С. 24-39.

3. Мацієвський Ю. В. У пастці гібридності: зигзаги трансформацій політичного режиму в Україні (1991-2014) : монографія. Чернівці : Книги - XXI, 2016. 552 с.

4. Кармазіна М. Пріоритети й орієнтири Президента України Віктора Ющенка Аналіз документів (23 січня 2005 р. - 24 лютого 2010 р.). Політичний менеджсмент. 2010. С.50-67.

5. Антонович И. И. Quo vadis, Украина? Пространство и время. 2014. № 2 (16). С. 25-33.

6. Про схвалення Концепції реформування місцевого самоврядування та територіальної організації влади в Україні: Розпорядження кабінету Міністрів України від від 1 квітня 2014 р. № 333-р. URL: https://zakon.rada.gov.ua/laws/show/333-2014-\%D1\%80\#Text (дата звернення: 30.01.2021).

7. Шведа Ю. «Революція гідності» в контексті загальної теорії соціальних революцій. 1 жовтня 2012. URL: https://cathedra.io.ua/s627660/yuriy_shveda._revolyuciya_gidnosti_v_konteksti_zagalnoe_teorie_socialnih_revolyuciy (дата звернення: 30.01.2021). 
8. Про очищення влади :Закон України від_16 вересня 2014 р. № 1682-VII. Вiдомості Верховної Ради (ВВР). 2014. № 44. ст.2041.

\section{References:}

1. Ukrainske suspilstvo. Monitorynh sotsialnykh zmin. Zbirnyk naukovykh prats. Zasnovanyi Instytutom sotsiolohii NAN Ukrainy. Kyiv, 2019. Vyp. 6 (20). 517 s.

2. Vyshniak O. Dovira do politychnykh instytutiv: poniattia, pokaznyky ta tendentsii zmin. Ukrainske suspilstvo 1992-2010. Sotsiolohichnyi monitorynh / za red. V. Vorony, M. Shulhy. Kyiv: In-t sotsiolohii NANU, 2010. S. 24-39.

3. Matsiievskyi Yu. V. U pasttsi hibrydnosti: zygzagy transformatsii politychnoho rezhymu v Ukraini (1991-2014) : monohrafiia. Chernivtsi : Knyhy - XXI, 2016. 552 c.

4. Karmazina M. Priorytety y oriientyry Prezydenta Ukrainy Viktora Yushchenka Analiz dokumentiv (23 sichnia 2005 r. - 24 liutoho 2010 r.). Politychnyi menedzhment. 2010. S.50-67.

5. Antonovych Y. Y. Quo vadis, Ukrayna? Prostranstvo y vremia. 2014. № 2 (16). S. 25-33.

6. Pro skhvalennia Kontseptsii reformuvannia mistsevoho samovriaduvannia ta terytorialnoi orhanizatsii vlady v Ukraini: Rozporiadzhennia kabinetu Ministriv Ukrainy vid vid 1 kvitnia 2014 r. № 333-r. URL: https://zakon.rada.gov.ua/laws/show/333-2014-\%D1\%80\#Text (data zvernennia: 30.01.2021).

7. Shveda Yu. «Revoliutsiia hidnosti» v konteksti zahalnoi teorii sotsialnykh revoliutsii. 1 zhovtnia 2012. URL: https://cathedra.io.ua/s627660/yuriy_shveda._revolyuciya_gidnosti_v_konteksti_zagalnoe_teorie_socialnih_revolyuciy (data zvernennia: 30.01.2021).

8. Pro ochyshchennia vlady :Zakon Ukrainy vid 16 veresnia 2014 r. № 1682-VII. Vidomosti Verkhovnoi Rady (VVR). 2014. № 44. st.2041.

\section{Melnyk J. P. Political Responsibility Institute Establishment in the Context of Public and Personal Interests During the Ukraine Independence}

The study of the dynamics of political responsibility in the context of personal and public interests, first of all, is combined with an understanding of the changing emphasis in the mutual responsibility of public authorities, political parties, civil society institutions, citizens and response in the form of public confidence, public activity, protest public mood and level of life satisfaction depending on the implementation of these changes and the implementation of state reforms. In order to determine the political responsibility effectiveness degree, the dynamics of the timeliness of its manifestation and the public response study according to the above criteria are subject to priority research.

It has been established that depending on the shift of public administration emphasis towards the parliamentary-presidential or presidential-parliamentary form of government in Ukraine, the instruments, procedure and distribution of political responsibility and, as a result, accountability and subordination of political system actors have changed. These «shifts of emphasis» were primarily justified by the requirements of the political situation within the country, public sentiment, declaring various vectors of domestic and foreign policy and taking as a basis the attitude of international organizations to domestic events and decisions.

The study of the peculiarities of political responsibility formation during the period of Ukraine's independence made it possible to establish five periods of change in the instrumental apparatus of political responsibility, which are directly related to the government form changei.

As a result of the study, two types of political responsibility not previously mentioned in the scientific literature were identified - changing the form of government as a political responsibility of the previous government, lustration as an instrument of political responsibility of civil servants.

Keywords: political responsibility, public and personal interests, government, political institution. political system. 